\title{
Reinterpret Mencius' the Debate between Human and Animal" from the Two Dimensions Construction Theory of Information Philosophy ${ }^{\dagger}$
}

\author{
Lu Wang \\ School of Humanities and Social Sciences, Xi' an Jiaotong University, Xianning West Road, No. 28, \\ Xi' an 710049, China; w100213680@163.com; Tel.: +86-153-9941-1504 \\ + Presented at the IS4SI 2017 Summit Digitalisation for a Sustainable Society, Gothenburg, Sweden, \\ 12-16 June 2017.
}

Published: 8 June 2017

\begin{abstract}
With the rapid development and inspiring enlightenment of biological sociology, it is found that the animal world is also quite complex, and the expression of their behavior and emotion also can be seen as good and evil, which is not unique to human beings. So Mencius' "four-mind of human nature" as the standard of distinguishing human and animal it could anew comprehend. This paper aims to deepen the cognition of Mencius' "four-mind of human nature" through the twodimension construction theory of information philosophy.
\end{abstract}

Keywords: philosophy of Information; four-mind of human nature; human; animal; two dimensions

\section{Introduction}

In recent years, information philosophy as essence philosophy have been proposed, and caused abroad attention. Professor Kun Wu put forward two-dimension construction theory of human in his «Information Philosophy». So from this sense Mencius" "four-mind of human nature" emphasize morality of human how to conduct oneself. It could anew comprehend that compared with twodimension construction theory of information philosophy. In Mencius' thought human kindness in its internal "four-mind of human nature", it is not a strict of scientific significance, apparently not even a universal inevitable fact. Then, why does Mencius insist and how do we understand the theoretical significance of his "good-in-nature theory".

\section{Mencius" "The Debate between Human and Animal"}

"Human who are different from animals in a few" [1] was fist put forward by Mencius in the «Mencius Gao Zi Upper» and thought that the difference between human and animals is "four-mind of human nature", that is, to sympathize, to feel shame and abhor, out of modesty and courtesy, and to tell from right and wrong, with the "kindheartedness view" as the core concept and "good-innature theory" as the starting point. In his view, human is born with the moral nature, "benevolence, justice, propriety and wisdom, not from the outside, was an inherent part of my mind" [1]. "The gentleman's nature, benevolence and wisdom" («Mencius»), nature is "four-mind of human nature", which is called "nature heart".

Of course, Mencius' theory of good-in-nature is not based on natural or empirical observations, but on the possibility of to be good. "Then if it is in love, it will be good in nature, that's called benevolence, and if not, it is not sin of the ability" [1]. Although his nature heart deposit, but it can also be Cattle grass on the hill, if not to take care of for a long time, or to trample it everywhere, also it may disappear, is not because "ability" in the birth. In Confucius's view. Such, even if the heinous, his nature mind still remains, and gave an example of "a child fell into the well", which speaks to the 
mind has a dominant in the practice of life. In addition, from his "nature-in-good" theory Mencius put forward a set of measures to preserve "the mind- to seek out the self". Of course, Mencius was making the "benevolence, righteousness, propriety and wisdom" of the traditional society and abstracting the essence of human nature, but it also distinguishes man and animals from the "fourmind of human nature". At a certain level, the Confucian traditional culture also embodies the guiding role of human dignity and moral ideals.

\section{Information Philosophy about Human's Two Dimensional Construction Theory}

In particular, in the human genetic structure, as a decisive genetic information concrete condensation in a fertilized cells in the mother's womb, internal information structure of the cell, provided general trends and possibilities of individual development. Another non-determinism type, only stipulate the construction of some potential or possible direction (physiological, psychological and behavioral activities), need to depend on the individual of the influence of the environment by the possible into reality [2]. The process of individual development, which is initiated by coding in the genetic code, is the first one-dimensional structure of the primitiveness generation of the individual. And genetic coding started by the ontogenesis of indeterminism type of program that is in the first dimension structure, on the basis of specialization of the second dimensional structure. But second dimensional structure construction of follow the rules of the evolution of the bifurcation, which direction is not a single, mainly depends on the individual's environment in the future, the environment not only refers to the social environment, but also the moral indoctrination, human freedom and subject selection. So the judgment of the difference between human and animal. The main distinction is in the non-deterministic manner.

As the example of a Wolf child, the Wolf child it inherited our human nature attribute, has the person's physical characteristics and physiological functions, from the level that is met the human's first dimension. However, because the later days out of the society, live in wolves and with Wolf habit in survival, even finally to be back to the circle of human society, but still out of place. Here can be regarded as "natural attribute" rather than real people, and its genetic code the ontogenesis of indeterminism type structure of the program in the first dimension is not smooth specialized constructed as the second dimension structure, build a person's social attributes, It is a failure that makes a man a true man.

\section{Conclusions}

Mencius told by the division of people and animals just as the division of the people's moral level, think of the person is the "compassion" behavior, such as the "four-mind of human nature", and from the practical point of view, they can not be directly observed in the outside. The standard of morality or goodness, in his view, is subjective internal and motivational. This is common in Confucianism which involves discussion of moral standards. «The Li. Kirecords»: "Confucius said that there benevolence conclude three aspects, the surface behavior is different, but the effect is same .The goal is the equal and same for the recognition and pursuit of benevolence, but the benevolence can not get to know" [3] the "benevolence" is the kindness motivation. Although behavior conform to social evaluation standard, if not out of "benevolence", but to make up for the sake of interests or fear of the law, although can accept such behavior, Not conform to the Confucian ethics of nature ethics moral.

At present moral types of diversification, is based on the different age, race, class and moral evaluation will appear differentiation. As is well known in the same time, the environment of nationality and class is likely to arise different moral different moral evaluation. The situation probably lies in the definition and understanding of moral is divided. It is moral to be ethical accord with code of ethics or morality is measured by kind motivation of virtue ethics. There is a lot of room here, so a voice of query will turn up. Whether there have a universal value evaluation standard for moral evaluation? As it were, a kind of commensurability ought to be as the evaluation criterion based on the angular of essence of human nature of "classes", otherwise the difference of subject itself will leads to different evaluation standards, and there is no way to communicate even reached a 
consensus.as thus, however, what about the moral standards of Mencius' moral ethics? We can not easily assume that Mencius' standards (which are the Confucian are casually mentioned. Different values conflicts is a fact that can not dissolving and in the circumstances of the history of the word and the globalization, and their communication, fusion and universal will also become a kind of inevitable trend.in this situation, it is very important to rational understand Mencius' original intention and insisting on the theory of the "four-mind of human nature".

Mencius' good-in-nature theory can be said to be "only human beings are likely to be good". Not everyone is necessarily for goodness at any times. This point can be evidenced by the saying that "from the instinctive nature, it can be good." As to why Mencius insisted "can be good" theory for the development of "good-in-nature", and above this, against far-reaching debate with the natural theory of human Gao Zi, which can be understood through dig into the development of Chinese society and culture of Mencius times facing the situation. Can think that the theory of good-in-nature is Mencius as the elite of Chinese culture to people out of the chaotic and spiritual consternation and lit a beacon, was the Chinese people urgently need to faith, and to put forward a kind of complicated social life has a value to theory framework. In brief, Mencius' theory of good-in-nature on the surface based on nature biological as properties of a "four-mind of human nature", is actually a reason of turning man into and animals development of some goodness is impossible, it with simple biological sense of the survival instinct cannot be mentioned in the same breath.

Conflicts of Interest: The authors declare no conflict of interest.

\section{References}

1. Yang, B.J. Mencius; ZhongHua Book Company: Beijing, China, 2016; pp. 251-323.

2. Wu, K. Information Philosophy Theory, System and Method; Commercial Press: Beijing, China, 2005; pp. $160-167$.

3. Wang, W. The Li.Ki; ZhongHua Book Company: Beijing, China, 2016; pp. 717-739.

(C) 2017 by the author. Licensee MDPI, Basel, Switzerland. This article is an open access article distributed under the terms and conditions of the Creative Commons Attribution (CC BY) license (http://creativecommons.org/licenses/by/4.0/). 